Review

\title{
Toxins for Transgenic Resistance to Hemipteran Pests
}

\author{
Nanasaheb P. Chougule and Bryony C. Bonning * \\ Department of Entomology, Iowa State University, 418 Science II, Ames, IA 50011, USA \\ * Author to whom correspondence should be addressed; E-Mail: bbonning@iastate.edu; \\ Tel.: +1-515-294-1989; Fax: +1-515-294-5957.
}

Received: 8 April 2012; in revised form: 16 May 2012 / Accepted: 25 May 2012 /

Published: 4 June 2012

\begin{abstract}
The sap sucking insects (Hemiptera), which include aphids, whiteflies, plant bugs and stink bugs, have emerged as major agricultural pests. The Hemiptera cause direct damage by feeding on crops, and in some cases indirect damage by transmission of plant viruses. Current management relies almost exclusively on application of classical chemical insecticides. While the development of transgenic crops expressing toxins derived from the bacterium Bacillus thuringiensis (Bt) has provided effective plant protection against some insect pests, Bt toxins exhibit little toxicity against sap sucking insects. Indeed, the pest status of some Hemiptera on Bt-transgenic plants has increased in the absence of pesticide application. The increased pest status of numerous hemipteran species, combined with increased prevalence of resistance to chemical insecticides, provides impetus for the development of biologically based, alternative management strategies. Here, we provide an overview of approaches toward transgenic resistance to hemipteran pests.
\end{abstract}

Keywords: Hemiptera; aphids; plant bug; Cry toxin; plant lectins; plant protease inhibitors; transgenic plants; insect resistance

\section{Hemiptera of Agricultural Importance}

\subsection{Hemiptera as Primary Pests}

Insects in the order Hemiptera feed exclusively on plant sap. Most hemipterans are phytophagous and impact multiple economically important crops. Most notable of the phytophagous hemipterans are aphids, plant bugs, stink bugs, psyllids and whiteflies. Initially recognized as only minor or secondary 
pests, these insects have become primary pests due in part to changes in agricultural practices, such as the increased use of transgenic and classically selected plant varieties resistant to primary pests, and the decline in application of chemical insecticides. The plant bugs (Lygus spp.) for example have emerged as a major pest on transgenic cotton engineered to express $B$ thuringiensis (Bt)-derived insecticidal toxins [1]. Hence, the hemipterans have directly benefited from the reduced application of chemical insecticides. Combined with the invasive nature and new found primary pest status, these pests negatively impact global agriculture, and currently present one of the biggest challenges for insect pest management.

Aphids (Hemiptera: Aphididae) are exclusive phloem feeders and are among the most economically important pest insects of temperate agriculture [2]. Aphids cause major economic losses on almost all crops, and account for a large part of the $13 \%$ of agricultural output estimated to be lost to insect pests $[3,4]$. Economic losses result from aphid feeding, which diverts plant nutrients essential for plant growth and reproduction. The parthenogenetic reproduction of apterous (wingless) aphids allows for rapid production of high population densities under favorable conditions, while alate (winged) aphids infest new host plants [5]. In addition to the impact of feeding, aphids also transmit plant viruses; more than 275 plant viruses, nearly 50\% of all insect-borne plant viruses are vectored by aphids [6,7]. Finally, aphids indirectly inhibit the photosynthetic ability of plants by producing honeydew, which allows sooty molds to grow on the leaf surface.

Several species of plant bugs (Lygus spp.; Hemiptera: Miridae) are major agricultural pests, including the Western tarnished plant bug, Lygus hesperus Knight, the tarnished plant bug, Lygus lineolaris (Palisot de Beauvois), and the green plant bug, Lygus elisus. L. hesperus and L. lineolaris are major pests of a wide range of agronomic and horticultural crops throughout the United States and Canada [8-11]. Lygus spp. are reported to feed on 117 non-crop plants and over 25 cultivated plants and are primarily known as pests of cotton (Gossypium hirsutum L.) and seed alfalfa (Medicago sativa L.) [12]. Nymphs and adults feed on the flowers and fruits of many plants causing abscission and deformation [13]. Additionally, Lygus bugs have been reported as plant disease vectors [9] and may potentially transmit cotton diseases [8].

Stink bugs (Hemiptera; Pentatomidae) comprise a pest complex of critical importance, impacting 12 major crops worldwide [14]. More than 50 closely related species of stink bugs affect crops including fruit, vegetable, nut, fiber, and cereals. The most abundant and important species include the green stink bug, Acrosternum hilare (Say); the Southern green stink bug, Nezara viridula (L.); and the brown stink bug, Euschistus servus (Say). Stink bug losses in U.S. cotton were estimated at \$64 million in 2005 and \$31 million in 2008, while losses in soybean, Glycine max L. Merrill, were up to $\$ 13$ million [15]. Other agronomic crops affected by the stink bug complex include corn, Zea mays L., grain sorghum, Sorghum bicolor L. [16], tomato, Solanum lycopersicum L. [17] and wheat, Triticum aestivum L. [18]. Additionally, the Southern green stink bug, $N$ viridula L., infected with an opportunistic Pantoea agglomerans (Ewing and Fife) strain can transmit this pathogen causing significant damage to cotton seed as well as lint [19].

Whiteflies (Hemiptera: Aleyrodidae) are phloem feeders with 1500 species distributed worldwide. Several phytophagous whitefly species are major agricultural pests, including the spiraling whitefly, Aleurodicus disperses Russell, the greenhouse whitefly, Trialeurodes vaporariorum (Westwood), and the sweet potato whitefly, Bemisia tabaci (Gennadius) [20,21]. Whiteflies affect the biochemistry, 
physiology, anatomy, and development of infested plants. Similar to aphids, whiteflies feed on plant nutrients essential for plant growth and development and induce phytotoxic effects by injecting saliva into the plant $[22,23]$. A few species, most notably B. tabaci, also transmit plant-damaging viral diseases $[24,25]$.

\subsection{Specialization for Ingestion of Plant Sap}

Hemiptera have evolved sophisticated feeding mechanisms by modification of their mouthparts into piercing-sucking structures. Their mouthparts consist of a needle-like stylet bundle with two mandibular and two maxillary stylets, and a narrow salivary canal that delivers saliva into the punctured plant tissue. The plant-feeding Hemiptera may be specialized to feed on phloem, xylem or mesophyll, or to feed on a combination of these tissues. Plant sap contains high concentrations of sugar $(0.15$ to $0.73 \mathrm{M})$, free amino acids $(15-65 \mathrm{mM})$ and proteins. The protein content in the phloem may vary from 0.3 to $60 \mathrm{mg} \mathrm{mL}^{-1}$ according to the plant species. Plant bugs and stink bugs use extra-oral digestion by secreting copious amounts of watery saliva into the feeding site, thereby digesting sap proteins using proteases present in the saliva [26]. These insects then ingest the predigested plant nutrients for further digestion by gut proteases and for nutrient uptake. Hence, these hemipterans ingest a low volume of nutritionally complete fluid, during discrete meals or feeding bouts, relative to other hemipterans (e.g., aphids) which feed continuously and ingest large volumes of nutritionally incomplete phloem or xylem sap. These insects process large volumes of dilute plant sap and therefore must regulate osmotic pressure in the gut and hemolymph. Some continuous feeders such as the leafhoppers Euscelidius variegatus and Eurymela distincta Signoret have a filter chamber to allow excess water from the anterior midgut to bypass the midgut and move directly into the hindgut and Malpighian tubules [27-29]. The midgut of the pea aphid has evolved to resist the osmotic pressure generated during sap ingestion [30,31]. The anterior midgut cells contain an apical network of lamellae instead of the usual regularly arranged-microvilli. These lamellae are interlinked through $15 \mathrm{~nm}$ trabaculae, which increases the resistance of the tissue to stretching.

\subsection{Management of Hemipteran Pests}

The most prevalent approach to the management of hemipteran pests is the application of classical chemical insecticides [32,33]. However, insecticides commonly lose efficacy with the development of insecticide resistance, most notably in aphids and whiteflies [34,35]. The adoption of aphid resistant crop cultivars has provided some success for the management of some species [32,36-39] and the use of natural enemies also holds promise [40,41].

Attempts to develop alternative tools for management of hemipteran pests including the use of $\mathrm{Bt}$ toxins are described below. Comprehensive information on Hemiptera-specific toxins, physiological factors contributing to the low sensitivity of Hemiptera to these toxins and potential strategies to develop more efficient insecticidal molecules are presented. 


\section{Insecticidal Toxins Derived from Bacillus thuringiensis}

B. thuringenesis ( $\mathrm{Bt}$ ) is a gram-positive, spore forming bacterium commonly found in soil. $\mathrm{Bt}$ produces $\delta$-endotoxin insecticidal proteins (Cry and Cyt toxins) during its sporulation stage. These toxins are active against a wide range of agriculturally and medically important pests with a high degree of specificity. Delta endotoxins are pore forming toxins that may induce cell death by forming ionic pores in the membrane of midgut epithelial cells in the target insect [42-45], or by triggering the activation of a cascade signaling pathway after toxin interaction with a specific receptor in the gut membrane [46]. The mode of action of Bt toxins is complex, involves multiple steps and sequential binding to receptors and is still incompletely understood. The ingested toxin is activated by insect gut proteases, interacts with the primary receptor and then undergoes further proteolytic processing. The toxin then binds to a second receptor resulting in toxin oligomerization and insertion into the membrane forming pores that cause osmotic shock, bursting of the midgut cells and insect death [45].

\subsection{Hemipteran-Active Bt Toxins}

Hemipteran pests with piercing and sucking mouthparts are not particularly susceptible to the effects of Bt toxins. Low level toxicity has been reported against aphids (Tables 1 and 2) [47,48] although the toxicity of the three Bt toxins used in this study (Cry2, Cry3 and Cry4) may have been underestimated due to the use of toxin crystals or spore suspension in feeding assays rather than presolubilized toxins. The approach used has the disadvantage that toxin solubilization would be inefficient due to the acidic $\mathrm{pH}$ in the aphid's stomach [49]. Solubilized forms of four Cry $\delta$-endotoxins (Cry1Ab, Cry3A, Cry4Aa and Cry11Aa) impacted survival of the pea aphid and retarded the growth of survivors [50]. Although these toxins showed greater aphid toxicity than previously reported, the toxicity levels were still low compared to the toxicity of some of the Cry toxins used for lepidopteran and coleopteran pest management in the field (LC50 of 1 and $3.56 \mu \mathrm{g} / \mathrm{mL}$ diet respectively; [51,52]). Cry3, Cry4Aa and Cry11Aa exhibited 100\% mortality with ST50 values (median survival time after challenge) of less than 3.7 days at $500 \mu \mathrm{g} / \mathrm{mL}$, while Cryl Ab exhibited only $25 \%$ mortality.

Table 1. Toxicity of $B$. thuringenesis $(\mathrm{Bt})$ toxins against aphids.

\begin{tabular}{|c|c|c|c|}
\hline Toxin & Toxicity & Specificity & Reference \\
\hline $\begin{array}{l}\text { Cry } 2, \text { Cry } 3 A, \\
\text { Cry } 4\end{array}$ & Some & $\begin{array}{l}\text { Potato aphid, } \\
\text { Macrosiphum euphorbiae }\end{array}$ & {$[48]$} \\
\hline Cry4Aa & LC50: $70-100 \mu \mathrm{g} / \mathrm{mL}$ & Pea aphid, & {$[50]$} \\
\hline Cry11Aa & $100 \%$ mortality at $500 \mu \mathrm{g} / \mathrm{mL}$ & Acyrthosiphon pisum & \\
\hline $\begin{array}{l}\text { Cry3A, } \\
\text { Vip1Ae-Vip2Ae }\end{array}$ & $\begin{array}{l}60 \% \text { mortality at } 500 \mu \mathrm{g} / \mathrm{mL} \\
\text { LC50: } 0.576 \mu \mathrm{g} / \mathrm{mL}\end{array}$ & $\begin{array}{l}\text { Cotton aphid, } \\
\text { Aphis gossypii }\end{array}$ & {$[53]$} \\
\hline
\end{tabular}


Table 2. Patented Bt toxins with toxicity against hemipteran insects.

\begin{tabular}{llll}
\hline Patent & Toxin & Specificity & Investigators \\
\hline US 2009/0,068,159 & TIC809, ET37, TIC810, TIC 812 & Lygus bugs and coleopteran pests & {$[54]$} \\
US 2010/0,064,394 & TIC853 & Lygus bugs & {$[55]$} \\
US 1993/5,262,159 & Bt isolates & Aphids & {$[47]$} \\
\hline
\end{tabular}

Vegetative insecticidal protein (Vip) purified from Bt isolates showed insecticidal activity against the cotton aphid, Aphis gossypii with an estimated LC50 of $0.576 \mu \mathrm{g} / \mathrm{mL}$ [53]. This Vip protein was identified as a binary toxin, Vip2Ae-Vip1Ae (Table 1). The recombinant, purified binary toxin bound to a $50 \mathrm{kDa}$ receptor from cotton aphid brush border membrane vesicles (BBMV), but did not bind to lepidopteran gut BBMV proteins suggesting that the toxin may have aphid specificity.

\subsection{Bases for Low Toxicity of Bt Toxins against Sap-Sucking Insects}

There are multiple factors that contribute to the low toxicity of Cry toxins against hemipteran pests. First, Bt toxins may not have evolved to kill hemipteran species as these pests are not exposed to the toxins. The bacterium B. thuriengiensis exists in the soil and is splashed on to the surface of foliage, and hence there is no natural selection for toxicity to Hemiptera, which pierce into the leaves, rather than feeding on the leaf surface [42]. The low susceptibility of these pests to Bt toxins may result from similarities between the glycoproteins of insect midgut microvilli, rather than as a result of direct selection for aphid toxicity [50].

A second factor that contributes to the relatively low toxicity of Bt toxins against Hemiptera, is that proteolytic activation of the ingested $\mathrm{Bt}$ toxin in the insect gut is essential for toxicity. The differences in the proteolytic enzymes (type, relative abundance) and gut milieu $(\mathrm{pH})$ between hemipteran and other pests are contributing factors for the low Bt toxicity against aphids [50,56]. The toxicity of Cry3A, Cry4A and Cry11A against the pea aphid was significantly increased when toxins were pre-activated with trypsin [50]. In the pea aphid gut, Bt toxins are proteolytically activated by cysteine proteases [56] (Figure 1). However, in contrast to serine proteases (trypsin and chymotrypsin) which are mostly responsible for toxin activation in the lepidopteran gut for example, most of the cysteine proteolytic activity is associated with the gut membrane, and hence potentially less accessible for degradation of gut contents. The same is true for cathepsin-L activity in the cotton aphid, A. gossypii [57]. Most of these agriculturally important sap-sucking pests have cysteine proteases in the gut which are active at more acidic $\mathrm{pH}$ relative to the alkaline conditions optimal for serine protease activity.

In the context of Cry toxin-mediated transgenic resistance, active toxins, rather than protoxins are expressed by the transgenic plants in some cases. However, intramolecular proteolytic cleavage is also important for toxicity against insects with neutral or acidic gut $\mathrm{pH}$ and hence is important for hemipteran-active toxins. Intramolecular proteolytic cleavage increases the solubility of the toxin in the gut thereby facilitating acquisition. For example, chymotrypsin-treated $67 \mathrm{kDa}$ Cry $3 \mathrm{~A}$ generates three polypeptides 49, 11 and $6 \mathrm{kDa}$ [58] whereas trypsin or T. molitor gut juices generate 55, 11 and $8 \mathrm{kDa}$ polypeptides. These polypeptides associate with each other and maintain insecticidal activity. Cry4Aa, which has some toxicity against the pea aphid [50], undergoes intramolecular proteolytic cleavage producing two protease-resistant fragments of 20 and $45 \mathrm{kDa}$ from the $60 \mathrm{kDa}$ active 
intermediate [59]. These two fragments associate with each other to form an active complex. A mutant resistant to intramolecular cleavage had reduced toxicity against Culex pipiens.

Although functional receptors for Cry toxins have not been identified in sap-sucking pests, some studies have been carried out to investigate the association of Cry toxins with specific tissues following Cry toxin ingestion [12,56]. Immunocytochemical analysis of L. hesperus tissues after feeding on trypsin-activated Cry1Ac and Cry2Ab showed differential association of the toxins [12]. CrylAc did not associate with any of the L. hesperus tissues indicating the lack of a specific midgut binding receptor, whereas Cry2 $\mathrm{Ab}$ showed extensive binding to brush border microvilli, the basement membrane of midgut epithelial cells, and to cellular structures within the hemolymph and fat body. However, Cry1Ac was associated with the pea aphid gut membrane fraction in feeding assays whereas Cry3Aa was not [56]. In competition pull down assay experiments, both toxins showed specific binding to pea aphid gut BBMV. These different results reported for Cry3Aa could result from incomplete activation of Cry3 Aa in the aphid gut and instability of the toxin. In most cases toxicity is correlated with receptor binding; however there are reports of toxins binding in resistant or non-susceptible insects $[60,61]$. Clearly, the interactions between Cry toxins and gut receptors are complex and need further investigation at the molecular level.

Figure 1. Diagram of generic insect gut and hemocoel showing target sites of Cry toxins, plant lectins and plant proteases inhibitors.

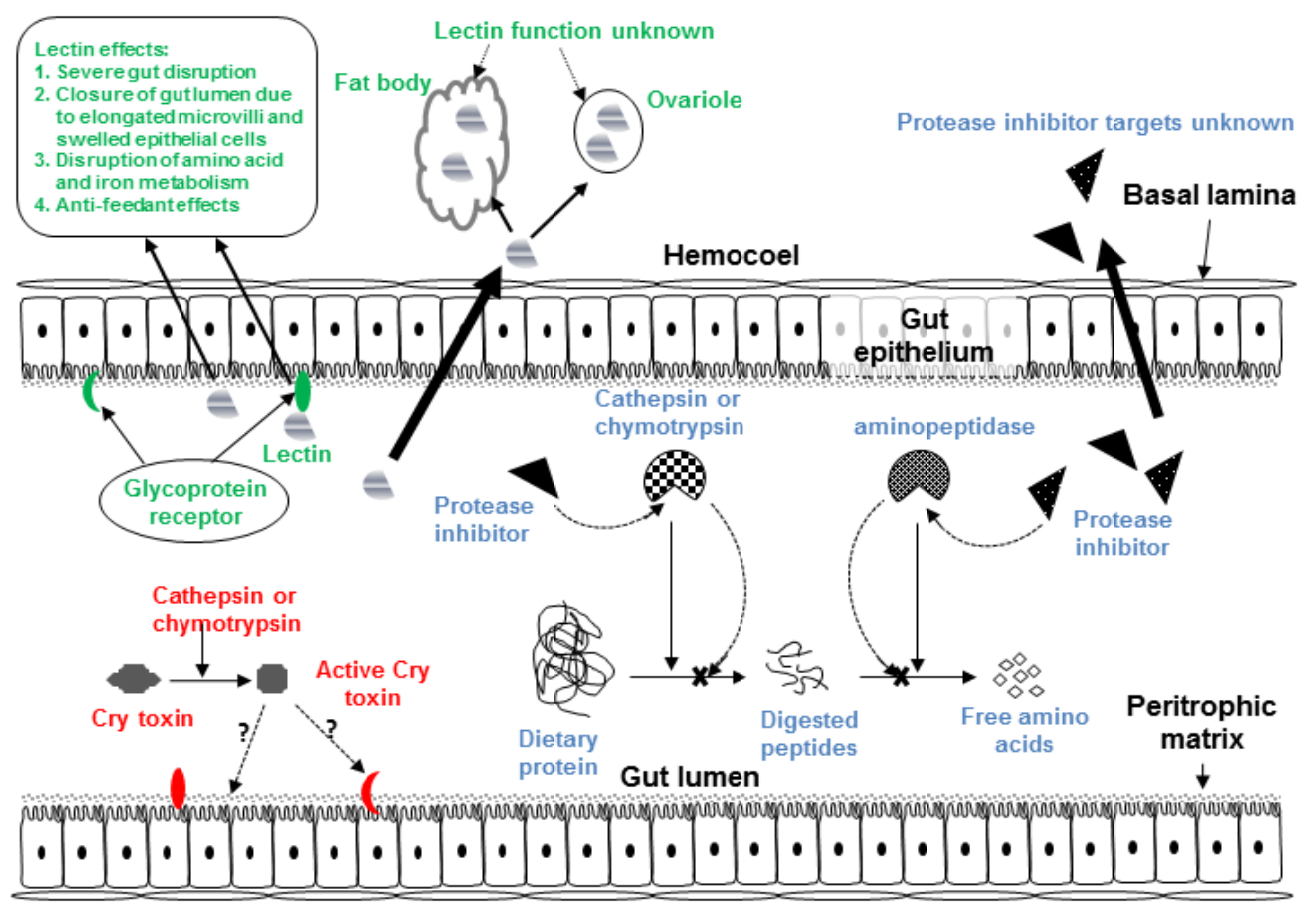

\subsection{Cry Toxin Modification for Enhanced Hemipteran Toxicity}

Despite extensive screening, relatively few toxins have been identified with significant toxicity against hemipteran pests (Tables 1 and 2) [53]. However, there is potential for modification of Cry toxins for improved efficacy against Hemiptera. 
Proteolytic activation of Cry toxins in the insect gut is an essential step for toxicity. This step has been extensively studied using Cry 1 toxins and involves the removal of 27-29 $\mathrm{N}$-terminal amino acids and 500-600 $C$-terminal amino acids. In hemipteran pests, acquisition of active toxin appears to be a limiting step as the midgut is slightly acidic or neutral and the majority of the endoproteolytic activity is of the membrane associated cathepsin L and B type [49,62,63]. Neither of these aspects is advantageous for activation of Cry toxins. Introduction of cathepsin protease-specific cleavage sites in the Cry toxin to facilitate activation and/or intramolecular cleavage for increased solubility as appropriate, provides an ideal way to maximize toxicity. Modification of Cry3A by introducing chymotrypsin/cathepsin $\mathrm{G}$ sites resulted in a three-fold increase in the toxicity towards larvae of the Western corn rootworm, Diabrotica virgifera [64].

Toxin modification for improved toxin binding to the insect gut resulted in toxins with activity against a broader range of pest species, and more sustainable levels of toxicity [65]. In this toxin modification strategy, Cry1Ac was fused to the nontoxic ricin B-chain, which is a galactose/ $N$-acetylgalactosamine binding lectin. This modified toxin had increased toxicity against a susceptible insect, the stem borer, Chilo suppressalis, as well as against a resistant insect, the cotton leaf worm, Spodoptera littoralis. Moreover, the modified toxin was also toxic to a hemipteran pest, the leafhopper, Cicadulina mbila, which is not susceptible to the native CrylAc. The ricin B-chain mediated Cry1Ac toxicity likely results from provision of additional toxin binding domains and consequent increased potential for interaction with gut receptor proteins.

\section{Plant Defense Proteins: Lectins}

Lectins are carbohydrate-binding proteins that are widely distributed in animals, plants and microorganisms [66-68]. Non-catalytic domains of these proteins bind reversibly to specific monosaccharides or complex glycans to carry out biological functions [69]. The physiological roles of plant lectins are widely debated, ranging from growth regulation [70], plant development [71], seed storage [72] and defense against pest and pathogens [73,74]. The role of lectins in plant defense against insect herbivory is of great interest and a broad spectrum of plant lectins has been tested for insecticidal activity.

Lectins vary widely in binding specificity, and mammalian toxicity. Indeed, lectins are present in a wide variety of plants including those that are commonly consumed such as beans, wheat, potato, and banana. Kidney bean lectin is the most well-known example of a lectin that can cause gastrointestinal stress if the beans are not processed correctly [75]. The snowdrop lectin, Galanthus nivalis agglutinin (GNA) is a monocot mannose-binding lectin that has received particular attention for toxicity against Hemiptera. Members of this group which include lectins from onion, leek and garlic, have no oral mammalian toxicity and are not harmful in raw or processed foods [76]. GNA is specific for the terminal $\alpha$-1-3-linked mannose. The $\alpha$-1-3-linked mannose residues are scarce in the brush border membranes of the mammalian small intestine. Studies using a rat model have shown that GNA is not toxic [77-79]. 


\subsection{Impact of Lectins on Herbivorous Insects}

The general effects of plant lectins on insect physiology such as fecundity, growth and development have been well documented [79]. Binding of plant lectins to the insect gut epithelium is a prerequisite for toxicity. Lectins appear to affect multiple insect physiological processes mediated by binding to glycoproteins on the gut membrane. GNA and ConA both bind the pea aphid gut membrane-anchored digestive enzyme aminopeptidase N (APN) [30]. APN is glycosylated with mannose, which is consistent with the binding specificities of GNA (mannose binding) and ConA (mannose and galactose binding). In contrast, wheat germ agglutinin (WGA), which has $N$-acetylglucosoamine carbohydrate specificity is not toxic to the pea aphid [80]. GNA binds to a ferritin subunit in the brown planthopper, Nilaparvata lugens and in $S$. littoralis causing interference with iron metabolism $[81,82]$. The toxicity of recombinant garlic lectin, Allium sativum agglutinin (ASAII), which is also insecticidal towards the pea aphid may result from interference with two physiological processes mediated by the gut membrane proteins, aminopeptidase N and sucrase [83]. The Arum maculatum tuber lectin ATL also bound specifically to glycoproteins in the midgut of the turnip aphid Lipaphis erysimi and Aphis craccivora resulting in insecticidal effects [84]. The jack bean lectin Concanavalin A agglutinin (Con A) binds to the entire digestive tract of the pea aphid resulting in altered amino acid metabolism and altered feeding behavior [85-87].

In addition to binding to the insect gut membrane, some GNA has been observed to cross the gut epithelium by an unknown mechanism [88]. In addition to altering midgut morphology, ingested GNA was detected in fat body, ovarioles, and hemolymph in $N$. lugens and could potentially affect multiple physiological processes at these sites [89].

\subsection{Hemipteran-Active Lectins}

As well as insecticidal activity against coleopteran [90-93] and lepidopteran insects [91,94], lectins are highly antinutritional and toxic to hemipterans. Lectins with specificity for mannose have the most severe effects on hemipteran pests (Table 3), although lectins with other carbohydrate specificities such as galactose, $\mathrm{N}$-acetylglucosoamine, $\mathrm{N}$-acetylgalactosoamine are also active against hemipteran pests such as aphids and Lygus bugs. GNA was the first plant lectin shown to have insecticidal activity towards aphid species and is perhaps the most studied lectin in terms of insecticidal properties. Transgenic expression of tobacco has improved resistance against the green peach aphid, Myzus persicae, by adversely affecting aphid populations [95,96]. Successful demonstration of the ability of GNA to provide protection against aphids led to subsequent testing of GNA for toxicity against different sap-sucking pests using a transgenic approach [97-100]. This investigation revealed that GNA is also toxic to the rice brown planthopper, Nilaparvata lugens, the cereal aphid, Sitobion avenae and the green leafhopper, Nephotettix virescens.

Lectins with similar binding specificity to GNA, such as the garlic lectins (Allium sativum agglutinins), also show toxicity against Hemiptera. Allium sativum produces four distinct lectins all with the same carbohydrate specificity. ASAI and ASAII are expressed in the garlic bulb while ASA-L is expressed in the leaves and ASA-R in the roots. ASA-L is toxic towards Hemiptera [101]. Transgenic tobacco and Indian mustard plants expressing ASA-L exhibited partial resistance to aphids, 
with reduced survival and fecundity [102,103]. Transgenic rice expressing ASA-L reduced the survival and fecundity of $N$. lugens and $N$. virescens [104,105]. These plants also showed decreased infection and replication of tungro viruses, which are transmitted by $N$. lugens and $N$. virescens. Transgenic chickpea plants expressing ASA-L under constitutive or phloem-specific promoters resulted in reduced survival and fecundity of the chickpea aphid, A. craccivora [106]. The mannose-binding Pinellia ternata agglutinin (PTA) exhibited significant insecticidal activities against hemipterans [107-109]. Transgenic plants expressing PTA negatively affected aphid population growth and were also toxic towards the brown planthopper. Comparative assessment of ASA-L with other GNA-like lectins (Dieffenbachia sequina agglutinin, DEA; Colocasia esculenta agglutin, CEA) for insecticidal effects against $A$. craccivora, showed that of those tested ASA-L was the most toxic [106]. Transgenic Indian mustard, Brassica juncea, expressing GNA, ASA-L, Allium cepa agglutinin (ACA, onion), and an ASA-L:ACA fusion protein negatively affected populations of the mustard aphid, Lipaphis erysimi with reduced survival and fecundity [110]. Survival and growth of green peach aphids, M. persicae, were severely affected by feeding on a diet containing the lectins GNA, Narcissus pseudonarcissus lectin (NPA), A. sativum agglutinin (ASA) or ConA [85].

Table 3. Lectins with toxicity against hemipteran pests.

\begin{tabular}{lll}
\hline $\begin{array}{l}\text { Lectin } \\
\text { (carbohydrate specificity) }\end{array}$ & $\begin{array}{l}\text { Target insect toxicity } \\
\text { (feeding assay/transgenic plant resistance) }\end{array}$ & References \\
\hline GNA: Galanthus nivalis & Aphids $(-/+)$ & {$[95,96]$} \\
agglutinin (Mannose) & Brown planthopper $(+/+)$ & {$[100,111,112]$} \\
& $\begin{array}{l}\text { Green peach aphid }(+/-) \\
\text { Pea aphid }(-/+)\end{array}$ & {$[85]$} \\
& Mustard aphid $(-/+)$ & {$[113]$} \\
ASA: Allium sativum agglutinin & Green peach aphid $(+/-)$ & {$[110]$} \\
(Mannose) & Brown planthopper $(-/+)$ & {$[85]$} \\
& Mustard aphid $(-/+)$ & {$[104,105]$} \\
& Chickpea aphid $(+/+)$ & {$[110]$} \\
ConA: Concanavalin A (Mannose, & Tobacco aphid $(-/+)$ & {$[106]$} \\
Galactose) & Green peach aphid $(+/+)$ & {$[114]$} \\
SNA-1: Sambucus nigra agglutinin & Pea aphid $(+/-)$ & {$[85,115]$} \\
(NeuAc(a-2,6)Gal/GalNAc) & Pea aphid $(+/-)$ & {$[116]$} \\
WGA: Wheat germ agglutinin & Mustard aphid $(+/-)$ & {$[117]$} \\
(N-Acetylglucosoamine) & Brown planthopper $(+/+)$ & {$[118]$} \\
NPA: Narcissus pseudonarcissus & Green peach aphid $(+/-)$ & {$[111]$} \\
agglutinin (Mannose) & & {$[85]$} \\
ATL: Arum maculatum tuber lectin & Chickpea aphid $(+/-)$ & {$[106]$} \\
(Mannose) & & {$[110]$} \\
ACA onion: Allium cepa agglutinin & Mustard aphid $(-/+)$ & {$[16,119]$} \\
(Galactose) & Pea aphid $(+/+)$ & \\
\hline & & \\
& &
\end{tabular}


Table 3. Cont.

\begin{tabular}{lll}
\hline $\begin{array}{l}\text { Lectin } \\
\text { (carbohydrate specificity) }\end{array}$ & $\begin{array}{l}\text { Target insect toxicity } \\
\text { (feeding assay/transgenic plant resistance) }\end{array}$ & References \\
\hline $\begin{array}{l}\text { DEA: Dieffenbachia sequina } \\
\text { agglutinin (thyroglobulin and } \\
\text { asialofetuin [120]; mannose and } \\
\begin{array}{l}\text { complex sugar moities) } \\
\text { CEA: Colocasia esculenta agglutinin } \\
\text { (thyroglobulin and asialofetuin [120]; }\end{array}\end{array}$ & Chickpea aphid (+/+) & {$[106]$} \\
$\begin{array}{l}\text { mannose and complex sugar moities) } \\
\text { PHA Phaseolus vulgaris agglutinin } \\
\text { (Galactose, } N \text {-Acetylgalactosoamine) }\end{array}$ & Western tarnished plant bug; & \\
$\begin{array}{l}\text { PTA: Pinellia ternata agglutinin } \\
\text { (Mannose) }\end{array}$ & Pea aphid; planthopper & {$[106]$} \\
\hline
\end{tabular}

The mannose and galactose binding lectin, ConA was highly toxic to pea aphid and green peach aphid $[85,115,116]$. Lectins with other carbohydrate specificities also exhibit toxicity against sap sucking pests in some cases. For example, the galactose-binding Amaranthus caudatus agglutinin (ACA) was toxic to the pea aphid and the cotton aphid, A. gossypii [116,119]. The $N$-acetylglucosamine binding lectin, wheat germ agglutinin (WGA) exerted negative effects on mustard aphid L. erysimi and $N$. lugens [111,118]. The N-acetylgalactosoamine/galactose binding lectin, phytohemagglutinin (PHA) from Phaseous vulgaris, binds preferentially to the midgut of the Western tarnished plant bug, L. hesperus Knight with deleterious consequences [121]. This study demonstrated the complex subcellular effects of PHA including severe disruption and elongation of the striated border microvilli and swelling of the epithelial cells which caused complete closure of the gut lumen. The fungal lectin, Sclerotinia sclerotiorum agglutinin (SSA), is toxic to the pea aphid with mortality resulting from lectin binding to the brush border membrane of the gut and induction of a signal transduction cascade leading to the death of midgut epithelial cells [122].

Endophytic fungi can effectively deliver lectins in plants to protect against sap-sucking pests [123]. Colonization of oilseed rape with a recombinant endophyte, Chaetomium globosum YY-11, expressing Pinellia ternate agglutinin (PTA) provided resistance against the green peach aphid.

\section{Antimetabolic Plant Protease Inhibitors}

Plant protease inhibitors (PIs) occur naturally in a wide range of plants as a part of their natural defense system against herbivores $[124,125]$. Through binding to digestive proteases of phytophagous insects, PIs impair digestion [126] and suppress growth and development of herbivores [124,127]. Research on PIs has been focused on identification of PIs effective against lepidopteran and coleopteran digestive proteases and insect gut protease-mediated adaptation to PIs [128-131]. However, transgenic plants expressing PIs had limited efficacy against the targeted lepidopteran and coleopteran pests, due to the ability of these insects to adapt by downregulating expression of the targeted proteases, and upregulating expression of gut proteases that were not susceptible to the PI.

In contrast, the use of PIs against sap feeding hemipteran pests has received limited attention. This relative lack of attention may result from the earlier premise that hemipteran insects lack proteolytic 
enzymes in the digestive tract, and instead rely on free amino acids in the phloem and xylem for their nutritional requirements. Inhibition of gut enzymes, including enyzmes other than proteases, is a potential area for development of transgenic resistance against hemipteran pests.

\subsection{The Digestive and Salivary Proteases of the Hemiptera}

The importance of proteolytic digestion in agriculturally important hemipteran species has only recently been recognized with the discovery of gut digestive proteolytic activity and a large number of genes coding for proteases [132]. The biochemical characterization of proteinase activity in the guts of the pea aphid, A. pisum and the green peach aphid, M. persciae resulted in identification of significant cysteine and aminopeptidase activities (Table 4) [49,116,133,134]. These gut enzymes are membrane associated to prevent being washed away by the large volumes of ingested phloem sap. The closely related aphid species, the cereal aphid, $S$. avenue also has cysteine and chymotrypsin-like proteolytic activity in the gut [135]. Cathepsin-L like proteolytic activity proposed to function in the processing of exogenous ingested polypeptides was detected from the cotton aphid, A. gossypii [57]. The genome sequence for the pea aphid contains a large family of genes encoding cathepsin B-like proteinases $[132,136]$. At least five of these proteins were highly expressed in the gut.

Table 4. Hemipteran gut proteases and protease inhibitors with hemipteran toxicity.

\begin{tabular}{|c|c|c|c|}
\hline Hemipteran pest & Proteolytic activity & Plant Protease inhibitors & References \\
\hline Pea aphid & $\begin{array}{l}\text { Cysteine and } \\
\text { aminopeptidase }\end{array}$ & $\begin{array}{l}\text { OC-I, Barley cystatin, } \\
\text { Bowman-Birk, Serpin }\end{array}$ & {$[49,132-134,137-140]$} \\
\hline Green peach aphid & $\begin{array}{l}\text { Cysteine and } \\
\text { aminopeptidase }\end{array}$ & OC-I & {$[116,138]$} \\
\hline Cotton aphid & Cathepsin-L like & OC-I & {$[57,138]$} \\
\hline Cereal aphid & $\begin{array}{l}\text { Cysteine and } \\
\text { chymotrypsin-like }\end{array}$ & & {$[135,141]$} \\
\hline $\begin{array}{l}\text { Plant bug, } \\
\text { Lygus hesperus }\end{array}$ & Aspartic and serine & & {$[62]$} \\
\hline $\begin{array}{l}\text { Plant bug, } \\
\text { Lygus lineolaris }\end{array}$ & $\begin{array}{l}\text { Serine and cysteine } \\
\text { trypsin-like and } \\
\text { chymotrypsin-like }\end{array}$ & & {$[26]$} \\
\hline Planthopper & $\begin{array}{l}\text { Trypsin and } \\
\text { cathepsin B-like }\end{array}$ & & {$[142]$} \\
\hline
\end{tabular}

Aspartic and serine proteolytic activity was detected in the gut of L. hesperus Knight, a major pest of cotton [62] and these enzymes were shown to be involved in digestion of dietary green fluorescent protein and casein [63]. The midgut associated serine proteolytic activity was resistant to inhibition by the protease inhibitor aprotinin whereas salivary proteolytic activity was susceptible, which indicates differences in the specificity of proteases present in the saliva and in the gut. Digestive proteases with diverse substrate specificities could explain why genetically engineered plants expressing higher levels of PIs did not affect some populations of Lygus [143]. Serine and cysteine proteolytic activities were detected in the closely related plant bug, L. lineolaris [26]. Biochemical characterization of the L. lineolaris gut proteases also showed the presence of trypsin-like and chymotrypsin-like serine 
proteolytic activity with one gene encoding a trypsin-like protease isolated [26]. Plant bugs have strong serine proteolytic activity in the salivary gland for extra-oral digestion of plant proteins $[26,144,145]$. It has been postulated that these salivary gland proteases enter the insect gut with the food slurry [146,147], which may complement gut digestive proteases for efficient digestion of dietary proteins. Another hemipteran pest, the silverleaf whitefly, Bemisia argentifolii digests ingested plant proteins to free amino acids which are used for de novo protein synthesis or excreted via honeydew [148] but gut proteolytic activity was not detected. Trypsin and cathepsin B-like proteolytic activity was detected in gut extracts from the rice brown planthopper, N. lugens [142].

\subsection{Insecticidal Effects of PIs against Hemiptera}

Although proteolytic activity has been detected in the guts of multiple hemipteran pests, a question remains about the functional role in gut proteolytic digestion to meet nutritional requirements. In theory, these insects do not require digestion of dietary protein for development, as they feed on phloem sap which contains free amino acids at concentrations ranging from $130 \mathrm{mM}-1050 \mathrm{mM}$ [149]. Nonetheless, PIs for inhibition of aphid gut proteases have been fed in diet or expressed in transgenic plants. A cystatin from rice, OC-I, reduced population growth up to $40 \%$ and reduced fecundity in the pea aphid, the cotton aphid and the green peach aphid, when fed at levels of up to $0.25 \mathrm{mg} / \mathrm{mL}$ [138]. A barley cysteine proteinase inhibitor, cystatin was toxic to the pea aphid (LC50 of $150 \mu \mathrm{g} / \mathrm{mL}$ ) whereas there was no significant mortality of the green peach aphid [133]. The impact of cystatin ingestion was correlated with a decrease in gut cathepsin protease activity. In contrast, cathepsins, as well as aminopeptidase activities increased in the green peach aphid after cystatin ingestion suggesting regulation of target and insensitive enzymes to overcome the effects of cystatin [133].

Notably, there are examples where PIs ingested by insects that lack the potential digestive target enzymes in the gut also resulted in insecticidal effects. These PIs appear to serve as defensive metabolites against phloem feeding insects but potentially by a different mechanism. The Bowman-Birk type of PI (a class of serine protease inhibitors) derived from pea seeds, exhibited insecticidal activity against the pea aphid with significant mortality [139]. Artificial cyclic peptides bearing the Bowman-Birk anti-chymotrypsin head induced the same effects on aphids indicating that the active site of this PI is responsible for the aphid toxicity. However, chymotrypsin-like proteolytic activity was not detected in aphid guts using two chromogenic chymotrypsin substrates. Chymotrypsin targeting PIs were shown to have anti-metabolic effects against three species of cereal aphid and pea aphid [137,141]. The anti-metabolic effects of PIs in the absence of the appropriate target gut protease have led to discussion of potential extra-digestive targets in these insects or an indirect PI effect on the regulation of production of digestive proteases [139,150,151].

As for any new approach for transgenic resistance against insect pests, appropriate assessment of the potential impact on nontarget organisms would be required prior to widespread deployment of transgenic plants in the field [152]. 


\section{Other Approaches}

Because of the challenges associated with management of hemipteran pests, specifically their insensitivity to $\mathrm{Bt}$ toxins and development of resistance to classical chemical insecticides, various additional strategies have been tested. Several alternative insecticidal molecules with Hemiptera-specific toxicity have been investigated [153].

A new Chromobacterium species isolated from insects, Chromobacterium subtsugae produces heat stable toxins that are highly toxic to the Southern green stink bug, $N$. viridula (L). Toxins produced by these bacteria killed $100 \%$ of the stink bug adults within six days [154]. Canatoxin (CNTX) from the seeds of Canavalia ensiformis (Leguminosae) are toxic to third instars of the cotton stainer bug, Dysdercus peruvianus, causing delayed development and eventual death [155]. This toxin was not toxic to adult insects, even at much higher concentrations, possibly due to the sensitivity of CNTX to gut proteases or to inefficient toxin activation in the adults.

Insect specific neurotoxins have also been investigated for toxicity against hemipteran pests such as the green peach aphid and the rice brown planthopper [156]. These toxins are not toxic on ingestion, but were fused to GNA, which serves as a delivery system for transport of the neurotoxin into the hemocoel [88]. GNA fused to the neurotoxic polypeptide, SF1, had significant toxicity against the rice brown planthopper in feeding assays, and reduced the survival of the green peach aphid. Avidin, derived from chicken egg white, is also toxic to the pea aphid but not to the cereal aphid [157]. The insecticidal effects of avidin are mediated by sequestering biotin, preventing absorption, causing biotin deficiency and affecting growth and survival. Pea albumin 1 (PA1b) extracted from pea seeds is toxic to several insect species, including some aphids $[158,159]$. PAlb is toxic to the pea aphid, toxic to the cotton aphid at high doses, but not toxic to the green peach aphid.

Aphid myosuppressins and myosuppressin analogs designed for increased peptide stability were incorporated into the pea aphid diet, and shown to be orally toxic with dose-dependent effects. Mortality reached $100 \%$ within ten days following ingestion of the most active aphid myosuppressin, Acypi-MS [160]. These peptides may act by inhibiting contraction of visceral muscles, and stimulating enzyme secretion from digestive tissues. Stabilized mimics of pyrokinin/pheromone biosynthesis activating neuropeptides (PK/PBAN) and tachykinin-related peptides also showed toxicity against the pea aphid, possibly through disruption of digestive processes through interference with gut motility [161,162].

Plant secondary metabolites have not only been investigated for insecticidal activity but also for their impact on insect behavior. Triterpene saponins of Quillaja saponaria for example, exhibited strong aphicidal activity mediated by cytotoxic effects on aphid gut epithelial cells. These saponins also had strong aphid deterrent activity [163].

\section{Conclusions and Future Outlook}

Although hemipteran insects are becoming primary insect pests on many economically important crop plants, we have only limited understanding of their feeding biology, gut physiology and ecology. The Hemiptera appear to be unique in many aspects of their biology. As they feed on sap from phloem or xylem tissue, they encounter weaker plant defenses compared to insects that feed on the storage and 
reproductive tissues of the plant for example. Moreover, the targets for insecticidal molecules that are effective against other pests are unique in these insects. For example, the putative receptors for $\mathrm{Bt}$ toxins in these insects appear to have diverged in sequence and possibly also in structure. Knowledge of potential insecticidal targets in key hemipteran pests will be essential for the development of effective insecticidal molecules for use in transgenic plants. This knowledge could then be used to identify native insecticidal molecules or to develop mutant insecticidal molecules by directed mutagenesis.

The silencing of genes through RNA interference (RNAi) has received much attention for pest management [164,165]. While this approach has been successful against coleopteran pests [166], results for RNAi in other insect pests including the Lepidoptera [167] and the Hemiptera [167-172], have been mixed and inconsistent, and are currently inadequate for use in the management of these pests. Identification of factors limiting the efficacy of RNAi in the Hemiptera may provide for future application of this approach for management purposes.

\section{Conflict of Interest}

The authors declare no conflict of interest.

\section{References}

1. Lu, Y.; Wu, K.; Jiang, Y.; Xia, B.; Li, P.; Feng, H.; Wyckhuys, K.A.G.; Guo, Y. Mirid bug outbreaks in multiple crops correlated with wide-scale adoption of Bt cotton in China. Science 2010, 328, 1151-1154.

2. Blackman, R.L. Aphids on the Worlds Crops. An Identification and Information Guide; John Wiley \& Sons: New York, NY, USA, 2000.

3. van Emden, H.; Harrington, R. Aphids as Crop Pests; CABI Publishing: London, UK, 2007; p. 717.

4. Faria, C.A.; Wackers, F.L.; Pritchard, J.; Barrett, D.A.; Turlings, T.C. High susceptibility of Bt maize to aphids enhances the performance of parasitoids of lepidopteran pests. PLoS One 2007, 2, e600.

5. Powell, G.; Tosh, C.R.; Hardie, J. Host plant selection by aphids: Behavioral, evolutionary, and applied perspectives. Annu. Rev. Entomol. 2006, 51, 309-330.

6. Miles, P.W. Specific Responses and Damage Caused by Aphidoidea. In Aphids. Their biology, Natural Enemies and Control; Minks, A.K., Harrewijn, P., Eds.; Elsevier: Amsterdam, The Netherlands, 1989; Volume C, pp. 23-47.

7. Sylvester, E.S. Viruses Transmitted by Aphids. In Aphids. Their Biology, Natural Enemies and Control; Minks, A.K., Harrewijn, P., Ed.; Elsevier: Amsterdam, The Netherlands, 1989; Volume C, pp. 65-88.

8. Esquivel, J.F.; Mowery, S.V. Host plants of the tarnished plant bug (Heteroptera : Miridae) in Central Texas. Environ. Entomol. 2007, 36, 725-730.

9. Wheeler, A.G., Jr. Biology of the Plant Bugs (Hemiptera: Miridae): Pests, Predators, Opportunists; Comstock Publishing Associates: Ithaca, NY, USA, 2001; pp. i-xv, 1-507.

10. Scott, D.R. An annotated listing of host plants of Lygus hesperus Knight. Bull. Entomol. Soc. Am. 1977, 23, 19-22. 
11. Young, O.P. Host plants of the tarnished plant bug, Lygus lineolaris (Heteroptera, Miridae). Ann. Entomol. Soc. Am. 1986, 79, 747-762.

12. Brandt, S.L.; Coudron, T.A.; Habibi, J.; Brown, G.R.; Ooagan, O.M.; Wagner, R.M.; Wright, M.K.; Backus, E.A.; Huesing, J.E. Interaction of two Bacillus thuringiensis $\delta$-endotoxins with the digestive system of Lygus hesperus. Curr. Microbiol. 2004, 48, 1-9.

13. Strong, F.E. Physiology of injury caused by Lygus hesperus. J. Econ. Entomol. 1970, 63, 808-814.

14. McPherson, J.E.; McPherson, R.M. Stink Bugs of Economic Importance in America North of Mexico; CRC Press: Boca Raton, FL, USA, 2000.

15. Reay-Jones, F.P.F. Spatial and temporal patterns of stink bugs (Hemiptera: Pentatomidae) in wheat. Environ. Entomol. 2010, 39, 944-955.

16. Young, W.R.; Teetes, G.L. Sorghum entomology. Annu. Rev. Entomol. 1977, 22, 193-218.

17. Michelbacher, A.E.; Middlekauff, W.W.; Bacon, O.G. Stink bug injury to tomatoes in California. J. Econ. Entomol. 1952, 45, 126-126.

18. Viator, H.P.; Pantoja, A.; Smith, C.M. Damage to wheat seed quality and yield by the rice stink bug and Southern green stink bug (Hemiptera, Pentatomidae). J. Econ. Entomol. 1983, 76, 1410-1413.

19. Medrano, E.G.; Bell, A.A. Role of Pantoea agglomerans in opportunistic bacterial seed and boll rot of cotton (Gossypium hirsutum) grown in the field. J. Appl. Microbiol. 2007, 102, 134-143.

20. Oliveira, M.R.V.; Henneberry, T.J.; Anderson, P. History, current status, and collaborative research projects for Bemisia tabaci. Crop Prot. 2001, 20, 709-723.

21. Faria, M.; Wraight, S.P. Biological control of Bemisia tabaci with fungi. Crop Prot. 2001, 20, 767-778.

22. Henneberry, T.J.; Jech, L.F.; Hendrix, D.L.; Steele, T. Bemisia argentifolii (Homoptera : Aleyrodidae) honeydew and honeydew sugar relationships to sticky cotton. Southwest. Entomol. 2000, 25, 1-14.

23. Chen, J.; McAuslane, H.J.; Carle, R.B.; Webb, S.E. Impact of Bemisia argentifolii (Homoptera : Auchenorrhyncha : Aleyrodidae) infestation and squash silverleaf disorder on Zucchini yield and quality. J. Econ. Entomol. 2004, 97, 2083-2094.

24. Brown, J.K.; Czosnek, H. Whitefly transmission of plant viruses. Adv. Bot. Res. 2002, 36, 65-100.

25. Colvin, J.; Omongo, C.A.; Govindappa, M.R.; Stevenson, P.C.; Maruthi, M.N.; Gibson, G.; Seal, S.E.; Muniyappa, V. Host-plant viral infection effects on arthropod-vector population growth, development and behaviour: Management and epidemiological implications. Plant Virus Epidemiol. 2006, 67, 419-452.

26. Zhu, Y.C.; Zeng, F.R.; Oppert, B. Molecular cloning of trypsin-like cDNAs and comparison of proteinase activities in the salivary glands and gut of the tarnished plant bug Lygus lineolaris (Heteroptera : Miridae). Insect Biochem. Mol. Biol. 2003, 33, 889-899.

27. Lindsay, K.L.; Marshall, A.T. Ultrastructure of the filter chamber complex in the alimentary canal of Eurymela distincta Signoret (Homoptera, Eurymelidae). Int. J. Insect Morphol. Embryol. 1980, 9, 179-198.

28. Cheung, W.W.K.; Purcell, A.H. Ultrastructure of the digestive system of the leafhopper Euscelidius variegatus Kirshbaum (Homoptera, Cicadellidae), with and without congenital bacterial infections. Int. J. Insect Morphol. Embryol. 1993, 22, 49-61. 
29. Martoja, R.; Ballan-Dufrancais, C. The Ultrastructure of Digestive and Excretory Organs. In Insect Ultrastructure; King, R.C., Akai, H., Eds.; Plenum Press: New York, NY, USA, 1984; Volume 2, pp. 199-268.

30. Cristofoletti, P.T.; de Sousa, F.A.; Rahbe, Y.; Terra, W.R. Characterization of a membrane-bound aminopeptidase purified from Acyrthosiphon pisum midgut cells. A major binding site for toxic mannose lectins. FEBS J. 2006, 273, 5574-5588.

31. Karley, A.J.; Ashford, D.A.; Minto, L.M.; Pritchard, J.; Douglas, A.E. The significance of gut sucrase activity for osmoregulation in the pea aphid, Acyrthosiphon pisum. J. Insect Physiol. 2005, 51, 1313-1319.

32. Ragsdale, D.W.; Landis, D.A.; Brodeur, J.; Heimpel, G.E.; Desneux, N. Ecology and management of the soybean aphid in north America. Annu. Rev. Entomol. 2011, 56, 375-399.

33. Bhatia, V.; Uniyal, P.L.; Bhattacharya, R. Aphid resistance in Brassica crops: Challenges, biotechnological progress and emerging possibilities. Biotechnol. Adv. 2011, 29, 879-888.

34. Devonshire, A.L. Resistance of Aphids to Insecticides. In Aphids, Their Biology, Natural Enemies and Control; Minks, A.K., Harrewijn, P., Eds.; Elsevier: Amsterdam, The Netherlands, 1989; Volume C, pp. 123-139.

35. Foster, S.P.; Harrington, R.; Dewar, A.M.; Denholm, I.; Devonshire, A.L. Temporal and spatial dynamics of insecticide resistance in Myzus persicae (Hemiptera: Aphididae). Pest Manag. Sci. 2002, 58, 895-907.

36. Diaz-Montano, J.; Reese, J.C.; Schapaugh, W.T.; Campbell, L.R. Characterization of antibiosis and antixenosis to the soybean aphid (Hemiptera : Aphididae) in several soybean genotypes. J. Econ. Entomol. 2006, 99, 1884-1889.

37. Hesler, L.S.; Dashiell, K.E.; Lundgren, J.G. Characterization of resistance to Aphis glycines in soybean accessions. Euphytica 2007, 154, 91-99.

38. Hill, C.B.; Li, Y.; Hartman, G.L. Resistance to the soybean aphid in soybean germplasm. Crop Sci. 2004, 44, 98-106.

39. Li, Y.; Hill, C.B.; Carlson, S.R.; Diers, B.W.; Hartman, G.L. Soybean aphid resistance genes in the soybean cultivars Dowling and Jackson map to linkage group M. Mol. Breed. 2007, 19, 25-34.

40. Pal, N.; Boyapalle, S.; Beckett, R.; Miller, W.A.; Bonning, B.C. A baculovirus-expressed dicistrovirus that is infectious to aphids. J. Virol. 2007, 81, 9339-9345.

41. Grenier, A.M.; Duport, G.; Pages, S.; Condemine, G.; Rahbe, Y. The phytopathogen Dickeya dadantii (Erwinia chrysanthemi 3937) is a pathogen of the pea aphid. Appl. Environ. Microbiol. 2006, 72, 1956-1965.

42. Schnepf, E.; Crickmore, N.; van Rie, J.; Lereclus, D.; Baum, J.; Feitelson, J.; Zeigler, D.R.; Dean, D.H. Bacillus thuringiensis and its pesticidal crystal proteins. Microbiol. Mol. Biol. Rev. 1998, 62, 775-806.

43. Knowles, B.H.; Ellar, D.J. Colloid-osmotic lysis is a general feature of the mechanism of action of Bacillus thuringiensis delta-endotoxins with different insect specificity. Biochim. Biophys. Acta 1987, 924, 509-518.

44. Grochulski, P.; Masson, L.; Borisova, S.; Pusztaicarey, M.; Schwartz, J.L.; Brousseau, R.; Cygler, M. Bacillus thuringiensis Cry1A(a) insecticidal toxin-crystal structure and channel formation. J. Mol. Biol. 1995, 254, 447-464. 
45. Bravo, A.; Gomez, I.; Conde, J.; Munoz-Garay, C.; Sanchez, J.; Miranda, R.; Zhuang, M.; Gill, S.S.; Soberon, M. Oligomerization triggers binding of a Bacillus thuringiensis Cry $1 \mathrm{Ab}$ pore-forming toxin to aminopeptidase $\mathrm{N}$ receptor leading to insertion into membrane microdomains. Biochim. Biophys. Acta-Biomembr. 2004, 1667, 38-46.

46. Zhang, X.; Candas, M.; Griko, N.B.; Taussig, R.; Bulla, L.A., Jr. A mechanism of cell death involving an adenylyl cyclase/PKA signaling pathway is induced by the Cry1 Ab toxin of Bacillus thuringiensis. Proc. Natl. Acad. Sci. USA 2006, 103, 9897-9902.

47. Payne, J.R.; Cannon, R.J.C. Use of Bacillus thuringiensis Isolates for Controlling Pests in the Family Aphididae. US Patent 5,262,159, 16 November 1993.

48. Walters, F.S.; English, L.H. Toxicity of Bacillus thuringiensis $\delta$-endotoxins toward the potato aphid in an artificial diet bioassay. Entomol. Exp. Appl. 1995, 77, 211-216.

49. Cristofoletti, P.T.; Ribeiro, A.F.; Deraison, C.; Rahbe, Y.; Terra, W.R. Midgut adaptation and digestive enzyme distribution in a phloem feeding insect, the pea aphid Acyrthosiphon pisum. J. Insect Physiol. 2003, 49, 11-24.

50. Porcar, M.; Grenier, A.M.; Federici, B.; Rahbe, Y. Effects of Bacillus thuringiensis $\delta$-endotoxins on the pea aphid (Acyrthosiphon pisum). Appl. Environ. Microbiol. 2009, 75, 4897-4900.

51. Ali, M.I.; Luttrell, R.G. Response estimates for assessing heliothine susceptibility to Bt toxins. J. Econ. Entomol. 2009, 102, 1935-1947.

52. Park, Y.; Abdullah, M.A.F.; Taylor, M.D.; Rahman, K.; Adang, M.J. Enhancement of Bacillus thuringiensis $\mathrm{Cry} 3 \mathrm{Aa}$ and $\mathrm{Cry} 3 \mathrm{Bb}$ toxicities to coleopteran larvae by a toxin-binding fragment of an insect cadherin. Appl. Environ. Microbiol. 2009, 75, 3086-3092.

53. Sattar, S.; Maiti, M.K. Molecular characterization of a novel vegetative insecticidal protein from Bacillus thuringiensis effective against sap-sucking insect pest. J. Microbiol. Biotechnol. 2011, 21, 937-946.

54. Baum, J.A.; Roberts, J.K.; Zhang, B.; Anderson, H.; Chay, C.A. Insecticidal compositions and methods for makeing insect-resistant transgenic plants. US 2009/0,068,159 A1, 12 March 2009.

55. Baum, J.; Flasinski, S.; Heck, G.R.; Penn, S.R.; Sukuru, U.R.; Shi, X. Novel hemipteran and coleopteran active toxin proteins from Bacillus thuringiensis. US 2010/0,064,394, 11 March 2010.

56. Li, H.R.; Chougule, N.P.; Bonning, B.C. Interaction of the Bacillus thuringiensis delta endotoxins Cry1Ac and Cry3Aa with the gut of the pea aphid, Acyrthosiphon pisum (Harris). J. Invertebr. Pathol. 2011, 107, 69-78.

57. Deraison, C.; Darboux, I.; Duportets, L.; Gorojankina, T.; Rahbe, Y.; Jouanin, L. Cloning and characterization of a gut-specific cathepsin L from the aphid Aphis gossypii. Insect Mol. Biol. 2004, 13, 165-177.

58. Carroll, J.; Convents, D.; van Damme, J.; Boets, A.; van Rie, J.; Ellar, D.J. Intramolecular proteolytic cleavage of Bacillus thuringiensis Cry3A delta-endotoxin may facilitate its coleopteran toxicity. J. Invertebr. Pathol. 1997, 70, 41-49.

59. Yamagiwa, M.; Esaki, M.; Otake, K.; Inagaki, M.; Komano, T.; Amachi, T.; Sakai, H. Activation process of dipteran-specific insecticidal protein produced by Bacillus thuringiensis subsp. israelensis. Appl. Environ. Microbiol. 1999, 65, 3464-3469. 
60. Garczynski, S.F.; Crim, J.W.; Adang, M.J. Identification of putative insect brush border membrane-binding molecules specific to Bacillus thuringiensis delta-endotoxin by protein blot analysis. Appl. Environ. Microbiol. 1991, 57, 2816-2820.

61. Aranda, E.; Sanchez, J.; Peferoen, M.; Guereca, L.; Bravo, A. Interactions of Bacillus thuringiensis crystal proteins with the midgut epithelial cells of Spodoptera frugiperda (Lepidoptera: Noctuidae). J. Invertebr. Pathol. 1996, 68, 203-212.

62. Wright, M.K.; Brandt, S.L.; Coudron, T.A.; Wagner, R.M.; Habibi, J.; Backus, E.A.; Huesing, J.E. Characterization of digestive proteolytic activity in Lygus hesperus Knight (Hemiptera : Miridae). J. Insect Physiol. 2006, 52, 717-728.

63. Habibi, J.; Brandt, S.L.; Coudron, T.A.; Wagner, R.M.; Wright, M.K.; Backus, E.A.; Huesing, J.E. Uptake, flow, and digestion of casein and green fluorescent protein in the digestive system of Lygus hesperus Knight. Arch. Insect Biochem. Physiol. 2002, 50, 62-74.

64. Walters, F.S.; Stacy, C.M.; Lee, M.K.; Palekar, N.; Chen, J.S. An engineered chymotrypsin/cathepsing site in domain I renders Bacillus thuringiensis Cry3A active against western corn rootworm larvae. Appl. Environ. Microbiol. 2008, 74, 367-374.

65. Mehlo, L.; Gahakwa, D.; Nghia, P.T.; Loc, N.T.; Capell, T.; Gatehouse, J.A.; Gatehouse, A.M.R.; Christou, P. An alternative strategy for sustainable pest resistance in genetically enhanced crops. Proc. Natl. Acad. Sci. USA 2005, 102, 7812-7816.

66. Glynn, L.E. Lectins N. Sharon and H. Lis. Chapman and Hall, London and New York, 127 pages, $£ 19.50$ (1989). Cell Biochem. Funct. 1990, 8, 190.

67. Kilpatrick, D.C. Mannan-binding lectin: Clinical significance and applications. Biochim. Biophys. Acta-Gen. Subj. 2002, 1572, 401-413.

68. van Damme, E.J.M.; Lannoo, N.; Peumans, W.J. Plant lectins. Adv. Bot. Res. 2008, 48, 107-209.

69. Peumans, W.J.; Vandamme, E.J.M. Lectins as plant defense proteins. Plant Physiol. 1995, 109, 347-352.

70. Howard, I.K.; Horton, C.B.; Sage, H.J. Studies on appearance and location of hemagglutinins from a common lentil during the life cycle of a plant. Arch. Biochem. Biophys. 1972, 149, 323-326.

71. Brill, L.M.; Evans, C.J.; Hirsch, A.M. Expression of MsLEC1- and MsLEC2-antisense genes in alfalfa plant lines causes severe embryogenic, developmental and reproductive abnormalities. Plant J. 2001, 25, 453-461.

72. Huang, G.L.; Huang, H.L.; Zhang, H.C.; Wang, P.G. Structure-function relations of carbohydrates by neoglycolipid arrays. Appl. Biochem. Biotechnol. 2006, 133, 211-215.

73. Rodrigues Macedo, M.L.; Damico, D.C.; Machado Freire, M.G.; Toyama, M.H.; Marangoni, S.; Novello, J.C. Purification and characterization of an $\mathrm{N}$-acetylglucosamine-binding lectin from Koelreuteria paniculata seeds and its effect on the larval development of Callosobruchus maculatus (Coleoptera: Bruchidae) and Anagasta kuehniella (Lepidoptera: Pyralidae). J. Agric. Food Chem. 2003, 51, 2980-2986.

74. Luo, Y.; Xu, X.; Liu, J.; Li, J.; Sun, Y.; Liu, Z.; Liu, J.; van Damme, E.; Balzarini, J.; Bao, J. A novel mannose-binding tuber lectin from Typhonium divaricatum (L.) Decne (family Araceae) with antiviral activity against HSV-II and anti-proliferative effect on human cancer cell lines. J. Biochem. Mol. Biol. 2007, 40, 358-367. 
75. Poulsen, M.; Schroder, M.; Wilcks, A.; Kroghsbo, S.; Lindecrona, R.H.; Miller, A.; Frenzel, T.; Danier, J.; Rychlik, M.; Shu, Q.; et al. Safety testing of GM-rice expressing PHA-E lectin using a new animal test design. Food Chem. Toxicol. 2007, 45, 364-377.

76. Peumans, W.J.; Damme, E.J.M.V. Prevalence, biological activity and genetic manipulation of lectins in foods. Trends Food Sci. Technol. 1996, 7, 132-138.

77. Pusztai, A.; Ewen, S.W.B.; Grant, G.; Peumans, W.J.; Damme, E.J.M.V.; Coates, M.E.; Bardocz, S. Lectins and also bacteria modify the glycosylation of gut surface receptors in the rat. Glycoconjugate 1995, 12, 22-35.

78. Pusztai, A.; Koninkx, J.; Hendriks, H.; Kok, W.; Hulscher, S.; Damme, E.J.M.V.; Peumans, W.J.; Grant, G.; Bardocz, S. Effect of the insecticidal Galanthus nivalis agglutinin on metabolism and the activities of brush boarder enzymes in the rat small intestine. Nutr. Biochem. 1996, 7, 677-682.

79. Vandenborre, G.; Smagghe, G.; van Damme, E.J. Plant lectins as defense proteins against phytophagous insects. Phytochemistry 2011, 72, 1538-1550.

80. Rahbe, Y.; Febvay, G. Protein toxicity to aphids - an in vitro test on Acythosiphon pisum. Entomol. Exp. Appl. 1993, 67, 149-160.

81. Du, J.P.; Foissac, X.; Carss, A.; Gatehouse, A.M.R.; Gatehouse, J.A. Ferritin acts as the most abundant binding protein for snowdrop lectin in the midgut of rice brown planthoppers (Nilaparvata lugens). Insect Biochem. Mol. Biol. 2000, 30, 297-305.

82. Sadeghi, A.; Smagghe, G.; Proost, P.; van Damme, E.J.M. Ferritin acts as a target site for the snowdrop lectin (GNA) in the midgut of the cotton leafworm Spodoptera littoralis. Insect Sci. 2008, 15, 513-519.

83. Fitches, E.; Wiles, D.; Douglas, A.E.; Hinchliffe, G.; Audsley, N.; Gatehouse, J.A. The insecticidal activity of recombinant garlic lectins towards aphids. Insect Biochem. Mol. Biol. 2008, 38, 905-915.

84. Majumder, P.; Mondal, H.A.; Das, S. Insecticidal activity of Arum maculatum tuber lectin and its binding to the glycosylated insect gut receptors. J. Agric. Food Chem. 2005, 53, 6725-6729.

85. Sauvion, N.; Rahbe, Y.; Peumans, W.J.; VanDamme, E.J. M.; Gatehouse, J.A.; Gatehouse, A.M.R. Effects of GNA and other mannose binding lectins on development and fecundity of the peach-potato aphid Myzus persicae. Entomol. Exp. Appl. 1996, 79, 285-293.

86. Sauvion, N.; Nardon, C.; Febvay, G.; Gatehouse, A.M.R.; Rahbe, Y. Binding of the insecticidal lectin Concanavalin A in pea aphid, Acyrthosiphon pisum (Harris) and induced effects on the structure of midgut epithelial cells. J. Insect Physiol. 2004, 50, 1137-1150.

87. Sauvion, N.; Charles, H.; Febvay, G.; Rahbe, Y. Effects of jackbean lectin (ConA) on the feeding behaviour and kinetics of intoxication of the pea aphid, Acyrthosiphon pisum. Entomol. Exp. Appl. 2004, 110, 31-44.

88. Fitches, E.; Woodhouse, S.D.; Edwards, J.P.; Gatehouse, J.A. In vitro and in vivo binding of snowdrop (Galanthus nivalis agglutinin; GNA) and jackbean (Canavalia ensiformis; Con A) lectins within tomato moth (Lacanobia oleracea) larvae; mechanisms of insecticidal action. J. Insect Physiol. 2001, 47, 777-787. 
89. Powell, K.S.; Spence, J.; Bharathi, M.; Gatehouse, J.A.; Gatehouse, A.M.R. Immunohistochemical and developmental studies to elucidate the mechanism of action of the snowdrop lectin on the rice brown planthopper, Nilaparvata lugens (Stal). J. Insect Physiol. 1998, 44, 529-539.

90. Gatehouse, A.M.R.; Dewey, F.M.; Dove, J.; Fenton, K.A.; Pusztai, A. Effect of seed lectins from Phaseolus vulgaris on the development of larvae of Callosobruchis maculatus-Mechanism of toxicity. J. Sci. Food Agric. 1984, 35, 373-380.

91. Czapla, T.H.; Lang, B.A. Effect of plant lectins on the larval development of European corn borer (Lepidoptera, Pyralidae) and Southern corn rootworm (Coleoptera, Chysomelidae). J. Econ. Entomol. 1990, 83, 2480-2485.

92. Murdock, L.L.; Huesing, J.E.; Nielsen, S.S.; Pratt, R.C.; Shade, R.E. Biological effects of plant lectins on the cowpea weevil. Phytochemistry 1990, 29, 85-89.

93. Janzen, D.H.; Juster, H.B.; Liener, I.E. Insecticidal action of phytohemagglutinin in black beans on a bruchid beetle. Science 1976, 192, 795-796.

94. Harper, S.M.; Crenshaw, R.W.; Mullins, M.A.; Privalle, L.S. Lectin binding to insect brush border membranes. J. Econ. Entomol. 1995, 88, 1197-1202.

95. Shi, Y.; Wang, M.B.; Powell, K.S.; Vandamme, E.; Hilder, V.A.; Gatehouse, A.M.R.; Boulter, D.; Gatehouse, J.A. Use of the rice sucrose synthase-1 promoter to direct phloem-specific expression of beta-glucuronidase and snowdrop lectin genes in transgenic tobacco plants. J. Exp. Bot. 1994, 45, 623-631.

96. Hilder, V.A.; Powell, K.S.; Gatehouse, A.M.R.; Gatehouse, J.A.; Gatehouse, L.N.; Shi, Y.; Hamilton, W.D.O.; Merryweather, A.; Newell, C.A.; Timans, J.C. Expression of snowdrop lectin in transgenic tobacco plants results in added protection against aphids. Transgenic Res. 1995, 4, 18-25.

97. Gatehouse, A.M.R.; Down, R.E.; Powell, K.S.; Sauvion, N.; Rahbe, Y.; Newell, C.A.; Merryweather, A.; Hamilton, W.D.O.; Gatehouse, J.A. Transgenic potato plants with enhanced resistance to the peach-potato aphid Myzus persicae. Entomol. Exp. Appl. 1996, 79, 295-307.

98. Rao, K.V.; Rathore, K.S.; Hodges, T.K.; Fu, X.; Stoger, E.; Sudhakar, D.; Williams, S.; Christou, P.; Bharathi, M.; Bown, D.P.; et al. Expression of snowdrop lectin (GNA) in transgenic rice plants confers resistance to rice brown planthopper. Plant J. 1998, 15, 469-477.

99. Stoger, E.; Williams, S.; Christou, P.; Down, R.E.; Gatehouse, J.A. Expression of the insecticidal lectin from snowdrop (Galanthus nivalis agglutinin; GNA) in transgenic wheat plants: Effects on predation by the grain aphid Sitobion avenae. Mol. Breed. 1999, 5, 65-73.

100. Foissac, X.; Loc, N.T.; Christou, P.; Gatehouse, A.M.R.; Gatehouse, J.A. Resistance to green leafhopper (Nephotettix virescens) and brown planthopper (Nilaparvata lugens) in transgenic rice expressing snowdrop lectin (Galanthus nivalis agglutinin; GNA). J. Insect Physiol. 2000, 46, 573-583.

101. Bandyopadhyay, S.; Roy, A.; Das, S. Binding of garlic (Allium sativum) leaf lectin to the gut receptors of homopteran pests is correlated to its insecticidal activity. Plant Sci. 2001, 161, $1025-1033$. 
102. Dutta, I.; Majumder, P.; Saha, P.; Ray, K.; Das, S. Constitutive and phloem specific expression of Allium sativum leaf agglutinin (ASAL) to engineer aphid (Lipaphis erysimi) resistance in transgenic Indian mustard (Brassica juncea). Plant Sci. 2005, 169, 996-1007.

103. Dutta, I.; Saha, P.; Majumder, P.; Sarkar, A.; Chakraborti, D.; Banerjee, S.; Das, S. The efficacy of a novel insecticidal protein, Allium sativum leaf lectin (ASAL), against homopteran insects monitored in transgenic tobacco. Plant Biotechnol. J. 2005, 3, 601-611.

104. Saha, P.; Dasgupta, I.; Das, S. A novel approach for developing resistance in rice against phloem limited viruses by antagonizing the phloem feeding hemipteran vectors. Plant Mol. Biol. 2006, $62,735-752$.

105. Saha, P.; Majumder, P.; Dutta, I.; Ray, T.; Roy, S.C.; Das, S. Transgenic rice expressing Allium sativum leaf lectin with enhanced resistance against sap-sucking insect pests. Planta 2006, 223, 1329-1343.

106. Chakraborti, D.; Sarkar, A.; Mondal, H.A.; Das, S. Tissue specific expression of potent insecticidal, Allium sativum leaf agglutinin (ASAL) in important pulse crop, chickpea (Cicer arietinum L.) to resist the phloem feeding Aphis craccivora. Transgenic Res. 2009, 18, 529-544.

107. Yao, J.H.; Pang, Y.Z.; Qi, H.X.; Wan, B.L.; Zhao, X.Y.; Kong, W.W.; Sun, X.F.; Tang, K.X. Transgenic tobacco expressing Pinellia ternata agglutinin confers enhanced resistance to aphids. Transgenic Res. 2003, 12, 715-722.

108. Yao, J.H.; Zhao, X.Y.; Liao, Z.H.; Lin, J.; Chen, Z.H.; Chen, F.; Song, J.; Sun, X.F.; Tang, K.X. Cloning and molecular characterization of a novel lectin gene from Pinellia ternata. Cell Res. 2003, 13, 301-308.

109. Zhang, H.-Y.; Wu, X.-J.; Tang, K.-X.; Wang, X.-D.; Sun, X.-F.; Zhou, K.-D. A primary study of transferring the Pinellia tenata agglutinin (pta) gene into rice and expression. Acta Genet. Sinica 2003, 30, 1013-1019.

110. Hossain, M.A.; Maiti, M.K.; Basu, A.; Sen, S.; Ghosh, A.K.; Sen, S.K. Transgenic expression of onion leaf lectin gene in Indian mustard offers protection against aphid colonization. Crop Sci. 2006, 46, 2022-2032.

111. Powell, K.S.; Gatehouse, A.M.R.; Hilder, V.A.; Vandamme, E.J. M.; Peumans, W.J.; Boonjawat, J.; Horsham, K.; Gatehouse, J.A. Different antimetabolic effects of related lectins towards nymphal stages of Nilaparvata lugens. Entomol. Exp. Appl. 1995, 75, 61-65.

112. Nagadhara, D.; Ramesh, S.; Pasalu, I.C.; Rao, Y.K.; Sarma, N.P.; Reddy, V.D.; Rao, K.V. Transgenic rice plants expressing the snowdrop lectin gene (gna) exhibit high-level resistance to the whitebacked planthopper (Sogatella furcifera). Theor. Appl. Genet. 2004, 109, 1399-1405.

113. Wang, Z.Y.; Zhang, K.W.; Sun, X.F.; Tang, K.X.; Zhang, J.R. Enhancement of resistance to aphids by introducing the snowdrop lectin gene gna into maize plants. J. Biosci. 2005, 30, 627-638.

114. Sadeghi, A.; Smagghe, G.; Broeders, S.; Hernalsteens, J.P.; De Greve, H.; Peumans, W.J.; van Damme, E.J. Ectopically expressed leaf and bulb lectins from garlic (Allium sativum L.) protect transgenic tobacco plants against cotton leafworm (Spodoptera littoralis). Transgenic Res.

2008, 17, 9-18. 
115. Gatehouse, A.M.R.; Davison, G.M.; Stewart, J.N.; Galehouse, L.N.; Kumar, A.; Geoghegan, I.E.; Birch, A.N.E.; Gatehouse, J.A. Concanavalin A inhibits development of tomato moth (Lacanobia oleracea) and peach-potato aphid (Myzus persicae) when expressed in transgenic potato plants. Mol. Breed. 1999, 5, 153-165.

116. Rahbe, Y.; Sauvion, N.; Febvay, G.; Peumans, W.J.; Gatehouse, A.M.R. Toxicity of lectins and processing of ingested proteins in the pea aphid Acyrthosiphon pisum. Entomol. Exp. Appl. 1995, $76,143-155$.

117. Shahidi-Noghabi, S.; van Damme, E.J.; Mahdian, K.; Smagghe, G. Entomotoxic action of Sambucus nigra agglutinin I in Acyrthosiphon pisum aphids and Spodoptera exigua caterpillars through caspase-3-like-dependent apoptosis. Arch. Insect Biochem. Physiol. 2010, 75, 207-220.

118. Kanrar, S.; Venkateswari, J.; Kirti, P.B.; Chopra, V.L. Transgenic Indian mustard (Brassica juncea) with resistance to the mustard aphid (Lipaphis erysimi Kalt.). Plant Cell Rep. 2002, 20, 976-981.

119. Wu, J.; Luo, X.; Guo, H.; Xiao, J.; Tian, Y. Transgenic cotton, expressing Amaranthus caudatus agglutinin, confers enhanced resistance to aphids. Plant Breed. 2006, 125, 390-394.

120. van Damme, E.J.M.; Nakamura-Tsuruta, S.; Smith, D.F.; Ongenaert, M.; Winter, H.C.; Rouge, P.; Goldstein, I.J.; Mo, H.; Kominami, J.; Culerrier, R.; et al. Phylogenetic and specificity studies of two-domain GNA-related lectins: Generation of multispecificity through domain duplication and divergent evolution. Biochem. J. 2007, 404, 51-61.

121. Habibi, J.; Backus, E.A.; Huesing, J.E. Effects of phytohemagglutinin (PHA) on the structure of midgut epithelial cells and localization of its binding sites in western tarnished plant bug, Lygus hesperus Knight. J. Insect Physiol. 2000, 46, 611-619.

122. Hamshou, M.; Smagghe, G.; Shahidi-Noghabi, S.; de Geyter, E.; Lannoo, N.; van Damme, E.J.M. Insecticidal properties of Sclerotinia sclerotiorum agglutinin and its interaction with insect tissues and cells. Insect Biochem. Mol. Biol. 2010, 40, 883-890.

123. Qi, G.; Lan, N.; Ma, X.; Yu, Z.; Zhao, X. Controlling Myzus persicae with recombinant endophytic fungi Chaetomium globosum expressing Pinellia ternata agglutinin. J. Appl. Microbiol. 2011, 110, 1314-1322.

124. Ryan, C.A. Protease inhibitors in plants - genes for improving defenses against insects and pathogens. Annu. Rev. Phytopathol. 1990, 28, 425-449.

125. Jongsma, M.A.; Beekwilder, J. Co-evolution of insect proteases and plant protease inhibitors. Curr. Protein Pept. Sci. 2011, 12, 437-447.

126. Broadway, R.M.; Duffey, S.S. The effect of dietary protein on the growth and digestive physiology of larval Heliothis zea and Spodoptera exigua. J. Insect Physiol. 1986, 32, 673-680.

127. Tamhane, V.A.; Chougule, N.P.; Giri, A.P.; Dixit, A.R.; Sainani, M.N.; Gupta, V.S. In vivo and in vitro effect of Capsicum annum proteinase inhibitors on Helicoverpa armigera gut proteinases. Biochim. Biophys. Acta-Gen. Subj. 2005, 1722, 156-167.

128. Broadway, R.M. Are insects resistant to plant proteainase inhibitors? J. Insect Physiol. 1995, 41, $107-116$.

129. Jongsma, M.A.; Bakker, P.L.; Peters, J.; Bosch, D.; Stiekema, W.J. Adaptation of Spodoptera exigua larvae to plant proteinase inhibitors by induction of gut proteinase activity insensitive to inhibition. Proc. Natl. Acad. Sci. USA 1995, 92, 8041-8045. 
130. Bown, D.P.; Wilkinson, H.S.; Gatehouse, J.A. Differentially regulated inhibitor-sensitive and insensitive protease genes from the phytophagous insect pest, Helicoverpa armigara, are members of complex multigene families. Insect Biochem. Mol. Biol. 1997, 27, 625-638.

131. Chougule, N.P.; Giri, A.P.; Sainani, M.N.; Gupta, V.S. Gene expression patterns of Helicoverpa armigera gut proteases. Insect Biochem. Mol. Biol. 2005, 35, 355-367.

132. Rispe, C.; Kutsukake, M.; Doublet, V.; Hudaverdian, S.; Legeai, F.; Simon, J.C.; Tagu, D.; Fukatsu, T. Large gene family expansion and variable selective pressures for cathepsin B in aphids. Mol. Biol. Evol. 2008, 25, 5-17.

133. Carrillo, L.; Martinez, M.; Alvarez-Alfageme, F.; Castanera, P.; Smagghe, G.; Diaz, I.; Ortego, F. A barley cysteine-proteinase inhibitor reduces the performance of two aphid species in artificial diets and transgenic Arabidopsis plants. Transgenic Res. 2011, 20, 305-319.

134. Kutsukake, M.; Shibao, H.; Nikoh, N.; Morioka, M.; Tamura, T.; Hoshino, T.; Ohgiya, S.; Fukatsu, T. Venomous protease of aphid soldier for colony defense. Proc. Natl. Acad. Sci. USA 2004, 101, 11338-11343.

135. Pyati, P.; Bandani, A.R.; Fitches, E.; Gatehouse, J.A. Protein digestion in cereal aphids (Sitobion avenae) as a target for plant defence by endogenous proteinase inhibitors. J. Insect Physiol. 2011, 57, 881-891.

136. The International Aphid Genomics. Genome sequence of the pea aphid Acyrthosiphon pisum. PLoS Biol. 2010, 8, e1000313.

137. Alvarez-Alfageme, F.; Maharramov, J.; Carrillo, L.; Vandenabeele, S.; Vercammen, D.; van Breusegem, F.; Smagghe, G. Potential use of a serpin from arabidopsis for pest control. PLoS One 2011, 6, e20278.

138. Rahbe, Y.; Deraison, C.; Bonade-Bottino, M.; Girard, C.; Nardon, C.; Jouanin, L. Effects of the cysteine protease inhibitor oryzacystatin (OC-I) on different aphids and reduced performance of Myzus persicae on OC-I expressing transgenic oilseed rape. Plant Sci. 2003, 164, 441-450.

139. Rahbe, Y.; Ferrasson, E.; Rabesona, H.; Quillien, L. Toxicity to the pea aphid Acyrthosiphon pisum of anti-chymotrypsin isoforms and fragments of Bowman-Birk protease inhibitors from pea seeds. Insect Biochem. Mol. Biol. 2003, 33, 299-306.

140. Consortium, I.A.G. Genome sequence of the pea aphid Acyrthosiphon pisum. PLoS Biol. 2010, 8 , e1000313.

141. Tran, P.; Cheesbrough, T.M.; Keickhefer, R.W. Plant proteinase inhibitors are potential anticereal aphid compounds. J. Econ. Entomol. 1997, 90, 1672-1677.

142. Foissac, X.; Edwards, M.G.; Du, J.P.; Gatehouse, A.M.; Gatehouse, J.A. Putative protein digestion in a sap-sucking homopteran plant pest (rice brown plant hopper; Nilaparvata lugens: Delphacidae) - identification of trypsin-like and cathepsin B-like proteases. Insect Biochem. Mol. Biol. 2002, 32, 967-978.

143. Wu, K.; Li, W.; Feng, H.; Guo, Y. Seasonal abundance of the mirids, Lygus lucorum and Adelphocoris spp. (Hemiptera : Miridae) on Bt cotton in northern China. Crop Prot. 2002, 21, 997-1002.

144. Zeng, F.R.; Zhu, Y.C.; Cohen, A.C. Molecular cloning and partial characterization of a trypsin-like protein in salivary glands of Lygus hesperus (Hemiptera : Miridae). Insect Biochem. Mol. Biol. 2002, 32, 455-464. 
145. Zeng, F.; Zhu, Y.; Cohen, A. Partial characterization of trypsin-like protease and molecular cloning of a trypsin-like precursor cDNA in salivary glands of Lygus lineolaris. Comp. Biochem. Physiol. B-Biochem. Mol. Biol. 2002, 131, 453-463.

146. Cohen, A.C. Organization of digestion and preliminary characterization of salivary trypsin-like enzymes in a predaceous heteropteran, Zelus renardii. J. Insect Physiol. 1993, 39, 823-829.

147. Cohen, A.C. Solid-to-liquid feeding: The inside(s) story of extra-oral digestion in predaceous arthropoda. Am. Entomol. 1998, 44, 103-115.

148. Salvucci, M.E.; Rosell, R.C.; Brown, J.K. Uptake and metabolism of leaf proteins by the silverleaf whitefly. Arch. Insect Biochem. Physiol. 1998, 39, 155-165.

149. Gattolin, S.; Newbury, H.J.; Bale, J.S.; Tseng, H.-M.; Barrett, D.A.; Pritchard, J. A diurnal component to the variation in sieve tube amino acid content in wheat. Plant Physiol. 2008, 147, 912-921.

150. Gatehouse, J.A. Prospects for Using Proteinase Inhibitors to Protect Transgenic Plants Against Attack by Herbivorous Insects. Curr. Protein Pept. Sci. 2011, 12, 409-416.

151. Bown, D.P.; Wilkinson, H.S.; Gatehouse, J.A. Regulation of expression of genes encoding digestive proteases in the gut of a polyphagous lepidopteran larva in response to dietary protease inhibitors. Physiol. Entomol. 2004, 29, 278-290.

152. Cowgill, S.E.; Atkinson, H.J. A sequential approach to risk assessment of transgenic plants expressing protease inhibitors: Effects on nontarget herbivorous insects. Transgenic Res. 2003, 12, 439-449.

153. Sadeghi, A.; van Damme, E.J.; Smagghe, G. Evaluation of the susceptibility of the pea aphid, Acyrthosiphon pisum, to a selection of novel biorational insecticides using an artificial diet. J. Insect Sci. 2009, 9, 1-8.

154. Martin, P.A.; Hirose, E.; Aldrich, J.R. Toxicity of Chromobacterium subtsugae to southern green stink bug (Heteroptera: Pentatomidae) and corn rootworm (Coleoptera: Chrysomelidae). J. Econ. Entomol. 2007, 100, 680-684.

155. Staniscuaski, F.; Ferreira-Dasilva, C.T.; Mulinari, F.; Pires-Alves, M.; Carlini, C.R. Insecticidal effects of canatoxin on the cotton stainer bug Dysdercus peruvianus (Hemiptera: Pyrrhocoridae). Toxicon 2005, 45, 753-760.

156. Down, R.E.; Fitches, E.C.; Wiles, D.P.; Corti, P.; Bell, H.A.; Gatehouse, J.A.; Edwards, J.P. Insecticidal spider venom toxin fused to snowdrop lectin is toxic to the peach-potato aphid, Myzus persicae (Hemiptera: Aphididae) and the rice brown planthopper, Nilaparvata lugens (Hemiptera: Delphacidae). Pest Manag. Sci. 2006, 62, 77-85.

157. Hinchliffe, G.; Bown, D.P.; Gatehouse, J.A.; Fitches, E. Insecticidal activity of recombinant avidin produced in yeast. J. Insect Physiol. 2010, 56, 629-639.

158. Gressent, F.; Da Silva, P.; Eyraud, V.; Karaki, L.; Royer, C. Pea Albumin 1 subunit b (PA1b), a promising bioinsecticide of plant origin. Toxins 2011, 3, 1502-1517.

159. Gressent, F.; Duport, G.; Rahioui, I.; Pauchet, Y.; Bolland, P.; Specty, O.; Rahbe, Y. Biological activity and binding site characteristics of the PA1b Entomotoxin on insects from different orders. J. Insect Sci. 2007, 7, 1-10. 
160. Down, R.E.; Matthews, H.J.; Audsley, N. Oral activity of FMRFamide-related peptides on the pea aphid Acyrthosiphon pisum (Hemiptera: Aphididae) and degradation by enzymes from the aphid gut. Regul. Pept. 2011, 171, 11-18.

161. Nachman, R.J.; Hamshou, M.; Kaczmarek, K.; Zabrocki, J.; Smagghe, G. Biostable and PEG polymer-conjugated insect pyrokinin analogs demonstrate antifeedant activity and induce high mortality in the pea aphid Acyrthosiphon pisum (Hemiptera: Aphidae). Peptides 2012, 34, 266-273.

162. Nachman, R.J.; Mahdian, K.; Nassel, D.R.; Isaac, R.E.; Pryor, N.; Smagghe, G. Biostable multi-Aib analogs of tachykinin-related peptides demonstrate potent oral aphicidal activity in the pea aphid Acyrthosiphon pisum (Hemiptera: Aphidae). Peptides 2011, 32, 587-594.

163. de Geyter, E.; Smagghe, G.; Rahbe, Y.; Geelen, D. Triterpene saponins of Quillaja saponaria show strong aphicidal and deterrent activity against the pea aphid Acyrthosiphon pisum. Pest Manag. Sci. 2012, 68, 164-169.

164. Huvenne, H.; Smagghe, G. Mechanisms of dsRNA uptake in insects and potential of RNAi for pest control: A review. J Insect Physiol. 2010, 56, 227-235.

165. Price, D.R.; Gatehouse, J.A. RNAi-mediated crop protection against insects. Trends Biotechnol. 2008, 26, 393-400.

166. Baum, J.A.; Bogaert, T.; Clinton, W.; Heck, G.R.; Feldmann, P.; Ilagan, O.; Johnson, S.; Plaetinck, G.; Munyikwa, T.; Pleau, M.; et al. Control of coleopteran insect pests through RNA interference. Nat. Biotechnol. 2007, 25, 1322-1326.

167. Terenius, O.; Papanicolaou, A.; Garbutt, J.S.; Eleftherianos, I.; Huvenne, H.; Kanginakudru, S.; Albrechtsen, M.; An, C.; Aymeric, J.L.; Barthel, A.; et al. RNA interference in Lepidoptera: An overview of successful and unsuccessful studies and implications for experimental design. J. Insect Physiol. 2011, 57, 231-245.

168. Pitino, M.; Coleman, A.D.; Maffei, M.E.; Ridout, C.J.; Hogenhout, S.A. Silencing of aphid genes by dsRNA feeding from plants. PLoS One 2011, 6, e25709.

169. Jaubert-Possamai, S.; Le Trionnaire, G.; Bonhomme, J.; Christophides, G.K.; Rispe, C.; Tagu, D. Gene knockdown by RNAi in the pea aphid Acyrthosiphon pisum. BMC Biotechnol. 2007, 7, 63.

170. Zha, W.; Peng, X.; Chen, R.; Du, B.; Zhu, L.; He, G. Knockdown of Midgut Genes by dsRNA-Transgenic Plant-Mediated RNA Interference in the Hemipteran Insect Nilaparvata lugens. PLoS One 2011, 6, e20504.

171. Upadhyay, S.K.; Chandrashekar, K.; Thakur, N.; Verma, P.C.; Borgio, J.F.; Singh, P.K.; Tuli, R. RNA interference for the control of whiteflies (Bemisia tabaci) by oral route. J. Biosci. 2011, 36, $153-161$.

172. Mutti, N.S.; Louis, J.; Pappan, L.K.; Pappan, K.; Begum, K.; Chen, M.-S.; Park, Y.; Dittmer, N.; Marshall, J.; Reese, J.C.; Reeck, G.R. A protein from the salivary glands of the pea aphid, Acyrthosiphon pisum, is essential in feeding on a host plant. Proc. Natl. Acad. Sci. USA 2008, 105, 9965-9969.

(C) 2012 by the authors; licensee MDPI, Basel, Switzerland. This article is an open access article distributed under the terms and conditions of the Creative Commons Attribution license (http://creativecommons.org/licenses/by/3.0/). 